\title{
Factors Affecting Intention to use Mobile Money Service in Sri Lanka: Moderating Effect of Demographic Factors with reference to Western Province of Sri Lanka
}

\author{
Sanjeewa, H.H.D. ${ }^{1}$, Yatigammana, M.R.K.N. ${ }^{2}$ \\ ${ }^{1}$ Regional Planning and Optimization, Technology Strategy, Planning and Development, \\ Dialog Axiata PLC. \\ ${ }^{2}$ Department of Commerce and Financial Management, University of Kelaniya, Sri Lanka. \\ ${ }^{1}$ dinesh.sanjeeva@dialog.lk, ${ }^{2}$ kaushalya@kln.ac.lk
}

\begin{abstract}
Mobile money service allows mobile users to perform financial transactions using their mobile phones which helps to decline the physical use of money. Therefore, the objective of the study was to identify the factors affecting intention to use mobile money service in Sri Lanka and the relationship between those identified factors and intention to use mobile money services. Further, the study is carried out to assess the moderating impact of demographic factors on the relationship between those factors and the intention to use mobile money. The data collection was carried out through a structured questionnaire from 400 randomly selected participants of Western province Sri Lanka. Usefulness, trust, risk, awareness, and knowledge are identified as the key factors affecting the intention to use mobile money service. There was a significant positive relationship between usefulness, trust, awareness, and knowledge with the intention to use mobile money while the risk was significantly negative. Further, the moderating impact of demographic factors on the above-identified five factors was assessed and it was noted that gender and age do not moderate the relationship between the aboveidentified five factors and user intention, but income level and job title moderate the relationship between above-identified factors and user intention. Based on the results of the study it is recommended that mobile telecom operators should take actions to increase usefulness, trust, awareness and knowledge while taking actions to decrease the risk factors involving in the service. Further, it is recommended to consider education level and working experience as moderating demographic factors of factors effecting on intention to use mobile money services.
\end{abstract}

Keywords: Demographic factors, Intention to use, Mobile Money, Risk, Trust

Copyright: (C) 2021 Sanjeewa, H.H.D., Yatigammana, M.R.K.N. This is an open access article distributed under the Creative Commons Attribution License, which permits unrestricted use, distribution, and reproduction in any medium, provided the original work is properly cited.

Correspondence: dinesh.sanjeeva@dialog.lk

ORCID of authors: Yatigammana M.R.K.N. - (D) https://orcid.org/0000-0002-8057-8632

DOI: http://doi.org/10.4038/kjm.v10i2.7696 


\section{Introduction}

Technologies have a strong impact on our lives. Considering the tremendous growth of ICT technologies, the internet has created an incredible market space. Alongside the Internet, another technology stream has emerged to play an increasingly important role in business and society that is mobile communications. Telecommunication and wireless mobile network have grown exponentially in the area of facilities and equipment of mobile devices, standards and network implementation, and user acceptance. Those are likely to create new opportunities for users, businesses, and services providers (Anckar and Walden, 2003).

This new type of commerce, Mobile commerce (m-commerce), is starting another era of innovation in business and it will continue to extend the way organizations perform business and will change the relationships between companies, customers, suppliers, and partners (Anckar and Walden, 2003). Jenkins (2008) defined mobile money as money that can be accessed and used via mobile phones.

The main advantage of mobile money is the access takes place using mobile communication networks, making available these services independent of the geographic location of the user (Hohenberg and Rufera, 2004). The introduction of mobile money had brought new challenges and opportunities for businesses and individuals as the providers who offer mobile money service create a competitive landscape in the markets that reflects directly on the adoption of mobile money services (Jensen, 2017; GSMA Mobile Money, 2017).

In developing markets more than one billion customers have access to a mobile phone, but do not have a formal bank account (Molla, 2015). Mobile money allows peer-to-peer transfers between basic mobile devices by simple short messaging service using cash-in and cash-out services that are provided by agents (Jack and Suri, 2014).

However, contributions to global mcommerce debates from south Asian countries like Sri Lanka perspectives are rare.

As per the Telecommunication Regulatory Commission of Sri Lanka TRCSL, at present, there are four mobile operators in Sri Lanka and mobile market has already passed the $100 \%$ subscriber penetration milestone. (Telecommunication Regulatory Commission of Sri Lanka, 2018).

When considering the limited market in a country like Sri Lanka, four mobile operators create huge competition to capitalize on the market share by acquiring new customers. As businesses become complex, innovation is inevitable for the businesses to remain competitive, so the product and service innovation is essential for their survival and therefore devote considerable resources to the development of new products (Srinivasan, and Rangaswamy, 2002). Silva and Yapa (2013) argued that the strategic approach to survive in the market place is retaining new customers and diversify the business to other possible areas. It will be the solution for the competitiveness. As a result, with a competitive market for mobile phones, mobile operators in Sri Lanka have launched a number of new products into the market as stated. One of the key innovations was account-based mobile payment systems (Mobile Money). That convert e-money into physical money for e-money holders on their request, directly or through appointed merchants (Castri, 2013). This Guideline marks the significant changes in mobile money services, where two main mobile operators launched the money wallet system as their e-money services named eZ cash service by Dialog Axiata PLC and mCash service by Mobitel (Pvt) Ltd.

Even though it arose as serving breaking innovation, it was revealed that when 
analyzing the TRCSL and Dialog Axiata Annual reports, only $22 \%$ of subscribers used their mobile money service, which is $78 \%$ of users are not yet accepted it is as a service for them.
The following Figure 1.1 details about the total mobile subscriber base in Sri Lanka, based on the TRCSL annual report, 2018 and Dialog mobile subscriber base and eZ Cash subscriber base, based on Dialog Axiata annual reports, from 2012 to 2018.

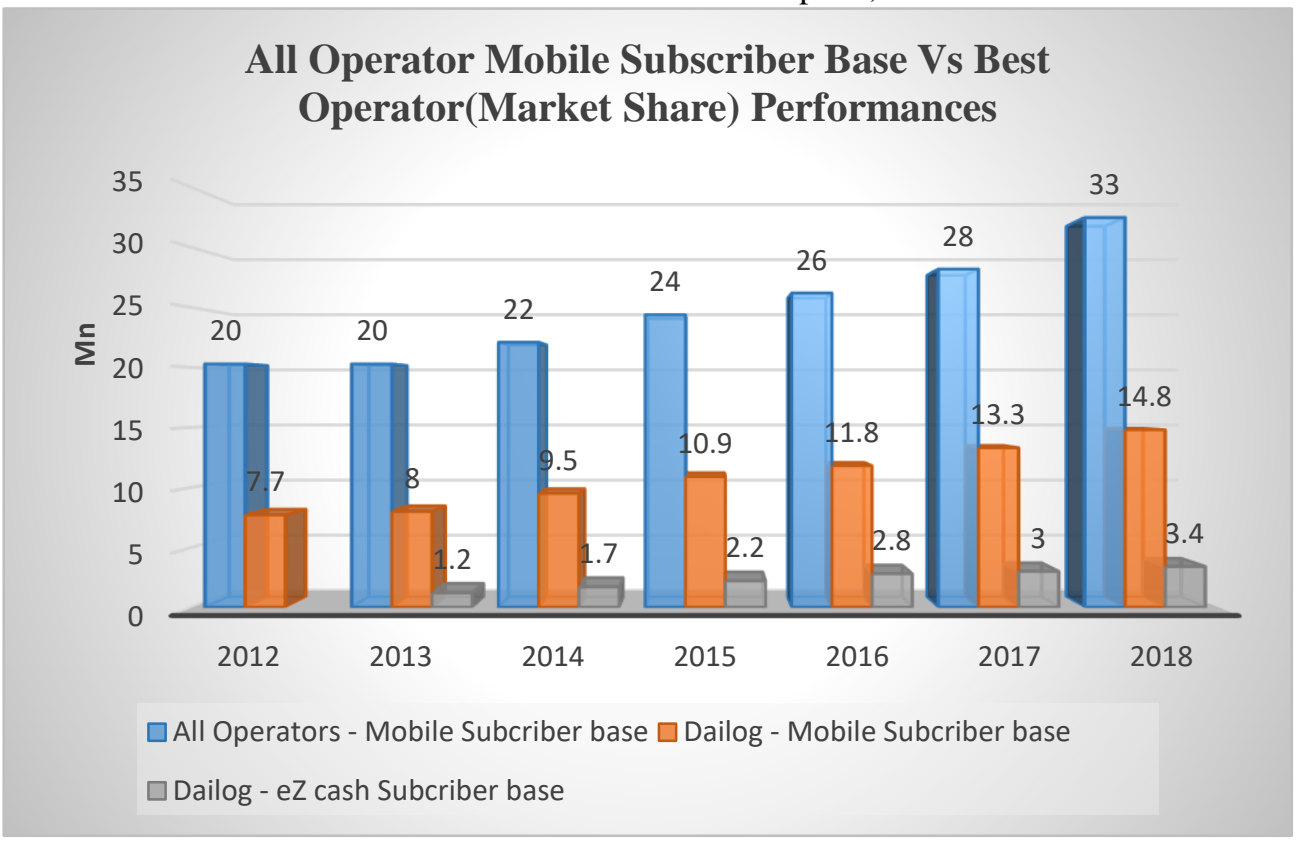

Figure 01: Mobile Subscriber Growth: 2012 - 2018

Source: TRCSL and Dialog Axiata PLC Annual reports - 2012 to 2018

Dialog is used as a bench mark for this analysis as Dialog is the number one Lanka with $45 \%$ market shares as of 2018 operator in terms of market share in Sri annual report.

\section{MOBLE MARKET SHARE - 2018}

- Other 4 Mobile Operators - Subcriber base Dailog - Mobile Subcriber base

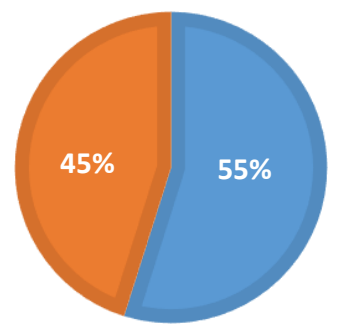

Figure 02: Mobile Market share

Source: TRCSL and Dialog Axiata PLC Annual reports, 2018 
It is clear with the above facts, there is a question with the user adaptation for this service despite it gives many advantages for the users.

\section{Review on Empirical Gap}

The study conducted by Chawla and Joshi (2018) stated that demographic differences caused to influence the degree of mobile banking adoption and recommended researchers to come up with improved mobile adoption frameworks and applications with greater understanding of the influence of demographic factors. Further researcher has recommended applying the similar model to other developing countries and seeing the cross-cultural comparison. Further, recommended to carry out a research if there exist any causal relationships between the antecedent variables and whether the causal relationship is moderated by demographic variables.

Further, a study conducted in Sri Lanka was found that awareness, knowledge and trust of the users have a positive relationship with use intention while perceived risk has a negative relationship with use intention for the mobile money services Sadaruwan, A., Samarasinghe, D., and Kuruppu, G. (2018). But user intention based on demographic factors were not analyzed during that study and samples were taken covering Colombo district IT sector executives only. it was recommended to undertake this for further studies covering other areas which will give better understanding about the user intention for the adoption of mobile money.

Therefore, this study will provide better understand about the impact of user adaptation on intention to use mobile money service based on demographic factors covering western province and thereby help to mitigate the empirical gaps under the research area of telecommunication industry with the suitable model for the local context.

\section{Review on Practice Gap}

Today's appearance of mobile financial services is characterized by use of mobile phone technology for the easy access of financial services. According to the research conducted by Sadaruwan et al., (2018). though the product was launched by two Sri Lankan Mobile operators in 2012 and 2013 respectively, they unable to capture the users to use their product and only around $20 \%$ of the registered user base is actively using these services. In other word, $80 \%$ of mobile users are not use this new service. Further, it was revealed that when analyzing the TRCSL (2018) annual report and Dialog Axiata (2018) Annual report, only $22 \%$ of subscribers used their mobile money service, eZ cash which made evidence that the intention to use mobile money of Sri Lankans is comparatively low comparing with the usage of mobile phones (Dialog Axiata PLC, 2018). In highlighting, when consider the mobile money service, which introduced by the mobile operators in Sri Lanka, are still trailing to adopt considerable customer base comparing with their usual voice and data services.

Further, it is supported by the article published Emonomynext (2019). According to them, use of mobile phones to do financial transactions is still low in Sri Lanka, with the island among the lowest in Asia, according to a new survey of mobile phone owners aged 15-65 years. Only five percent of Sri Lankans in that age group used mobile phones to send or receive money, according to the survey, 'After Access'. It studied how individuals access and use information and communications technologies (ICTs) in 23 countries of what is called the Global South "On a percentage basis, the use of mobile phones for financial transactions was very low in the Asian survey countries," said the survey, presented by the LIRNEasia thinktank. Bangladesh had the highest use of 30 percent among the Asian survey countries with the highest overall being in Kenya, at 86 percent, followed by Uganda at 80 percent. Sri Lanka has a mobile phone penetration rate connection per 100 persons of 150.1 , with the first effective mobile money transfer system launched by a mobile phone operator in 2012 followed by other mobile operators and later 
banks. The mobile phone penetration rate among the survey group under the mobile phone owners aged 15-65 years was 78 percent in Sri Lanka.

A study conducted in Sri Lanka was found that awareness, knowledge and trust of the users have a positive relationship with user intention while perceived risk has a negative relationship with user intention for the mobile money services (Sadaruwan et al., 2018). That study was limited to IT executives in the Colombo district in collecting the data and it was also another limitation of that research and will be addressed through this study. Also, it was limited to Colombo district and was recommended to undertake the similar studies covering other areas which will give better understanding about the user intention for the adoption of mobile money. Therefore, this study will provide better understand about the impact of user adaptation on intention to use mobile money service addressing above said limitations.

On the other hand, even though, there are many research articles are available in the field of mobile money related to banking sector, there is a limited number of studies done in telecommunication sector targeting mobile money services. It's hard to find even in lobal context. Further, factors effecting on intention to use mobile money service with the effect of demographic factors as moderator is rare to discovery. There is a dearth of studies done in Sri Lanka Telecommunication Sector to identify the impact of user adaptation on intention to use mobile money service by considering the demographic factors as moderator. Through this study, it is going to fill this practice gap as well.

\section{Objectives of the research}

To identify the factors affecting intention to use mobile money services in the Telecommunication Industry.
To assess the relationship of those factors affecting on intention to use mobile money services.

To examine the moderating effect of demographic factors for the relationship between factors affecting and intention to use mobile money services.

\section{Literature Review}

There is various kind of technologies developed in the industries of Medical (Wears and Berg, 2005), Electronic, Agriculture, Military, Telecommunication IT, etc (Li and Whalley, 2002). However, to clarify new technology as a successful technology, users must accept that technology and be able to use the technology for its intended purpose. This is more vibrant when the user acceptance literature in the technology arena is closely studied.

Rogers (1982), explained that different individuals have different degrees of adopting the new technology and the population is normally distributed over time. Futher more, models which are widely used in new technology acceptance area (Pura, 2005) are;

Theory of Reasoned Action (Fishbein, (1979)

Technology Acceptance Model (Davis, 1989)

However, After Analyzing above theoretical models and literature reviews, it was noted that all relevant variables are not included in single model which leads to select following factors as most influencing factors for user intention to accept new technologies specially when it's come to Sri Lankan context.

Perceived usefulness one creticle factor for buying decisions and it is defined as "the degree to which a person has faith in using a particular system would enhance his or her job performance", (Davis, 1989) and "using a specific application system will escalate his or her job performance "(Malhotra and Galletta, 1999). Customer's concern about 
the usefulness of the new services is also a crucial factor in determining the customers' adaption to the change, thus usefulness is one of the determinants of the intention to use new services like mobile payment services by customers (Venkatesh and Davis, 2000).

Tan and Teo, 2000 argued that usefulness will measure the willingness to adapt something new compared to the traditional values of the customers. According to Gong and $\mathrm{Xu}$ (2004), usefulness is considered as customers trust that their expectations will be achieved when applying new technologies. Awamieh and Fernandes (2005) named perceived usefulness as the new service which will offer more advantages than traditional services to individuals intending to use it. Naiwumbwe (2012) revealed that there is a significant relationship between perceived usefulness and intention to use and acceptance of mobile money services. Further, Chen, Gillenson, and Sherrell (2002) claimed that perceived usefulness is the main antecedent of intention to use online retailer and its websites.

Therefore, this research proposes that usefulness affects intention to use mobile money services.

H1: There is a positive relationship between Perceived Usefulness and the intention to use mobile money services

Laforet and $\mathrm{Li}$ (2005) as well as Tobbin (2013) discussed individual awareness as one of the factors that influence the acceptance and adoption of mobile money. Chen (2013) argued that individual awareness contributes to the adoption of mobile banking and lack of awareness is considered a barrier to mobile money adoption in developing countries ( $\mathrm{Yu}$ and Ibtasam, 2018).

Alkhunaizan and Love (2012) investigated and found that product awareness provides the familiarity about the existence of the product they wish to buy in the future and product awareness is the knowledge of the existence of the intended product or prior experience of similar products. Therefore, the information about the existence of the emoney service or prior experience creates user awareness and hence user intention to use the service (Alkhunaizan and Love, 2012). Jillbert and Ahmad (2003) conducted a study in Australia and used the awareness and knowledge about mobile commerce services as one of the factors affecting the adoption of $\mathrm{m}$-commerce services.

The awareness and attitude to change are found to influence the adoption of internet banking such in Malaysia (Suganthi et al., 2001). However, the consumers are not willing to accept that they do not have full control over their behavior. Sadaruwan et al., (2018). and argued that awareness is one of the key factors affecting the adoption of mobile money services and aware parties always to intend to use the service.

A previous study by Sathye (1999) concluded that the use of online banking services is a fairly new experience for many people, and low awareness of online banking is a major factor in causing people to do not adopt online banking.. In an empirical study, Sathye (1999) found that consumers are not aware of the possibilities, advantages, and disadvantages involved with online banking.

A study conducted in Malaysia by Suganthi and Balachandran (2001) focused on the factors that potentially influence internet banking adoption. The results revealed that there were positive significant relationships between awareness and internet banking adoption.

Thus, through this research proposes that awareness affects intention to use mobile money services.

$\mathrm{H} 2$ : There is a positive relationship between awareness and the intention to use mobile money services

Risk is defined as the lack of security during the paying process due to unexpected errors or transactions made without honesty between the buyer and the seller (Havlena and DeSarbo, 1991). 
Pavlou (2001) defined perceived risk is the user's subjective expectation of suffering a loss in pursuit of the desired outcome. Risk is also regarded as the loss of information leading to financial losses due to the disturbing hacker (Ganesan, 1994). The evaluation of risk level is calculated by the level at which an individual expects possible negative results or errors when a transaction is being proceeded (Peter and Tarpey, 1975). The quality of online services offered the possible risk of illegal activities and fraud has always been a concern for both consumer and service providers (Ba and Pavlou, 2002). The risk in mobile banking is perceived to be higher than conventional banking because information exchange on wireless infrastructure, which produced inherent doubts among consumers as hacking and other malicious attacks, might cause financial and personal data loss (Yousafzai, Pallister and Foxall, 2003).

Consumers' desire to minimize risk supersedes their willingness to maximize utility and thus their subjective risk perception strongly determines their behavior (Bauer, Barnes, Reichardt and Neumann, 2005). Thus, reducing uncertainty has been found to have a positive influence on consumers' intention to adopt electronic transactional systems (Chen, 2008). Sadaruwan et al., (2018) argued that perceived risk is one of the key factors affecting the adoption of mobile money services, and trusted parties always intend to use the service.

Thus, this research proposes that risk affects intention to use mobile money services

$\mathrm{H} 3$ : There is a negative relationship between risk and the intention to use mobile money services

Chiu, Bool and Chiu (2017) has given trust as the central determinant of relationships, an individual perceives the other party is trustworthy. It is a volitional vulnerability that influences an individual to such interaction to commit to the relationship (Holmes, 1991; Mayer, Davis and
Schoorman, 1995). Before an individual commits in interaction and relationship, the level of trust starts at zero (Lewicki, Tomlinson, and Gillespie, 2006). Moreover, a reliable mobile network is a critical component of mobile money service as customers have much less patience for transmission problems when they influence financial transactions (Lal and Sachdev, 2015). Thakur and Srivastava (2014) conducted a study on what keeps mobile banking customers loyal and reveal that trust is one of the factors of it.

Kim, Shin, and Lee, (2008) defined trust as a readiness to use the new service with a sense of ease, safety, and risk acceptance. Kim et al., (2008) stated that one party will honestly perform their duties with the hopes of the other party's confidence.

A study done by Bhattacherjee, (2002) argued that customer's trust is one of the key factors for the achievement of mobile banking in the context in which the transactions are made in a telephone network that is more vulnerable and uncertain than the traditional payment transaction. Trust in the payment system will help customers to use services easily and efficiently without much effort in the translation of online service.

Further, Amoroso and Watanabe (2012) observed that trust is especially important in influencing consumer behavior in uncertain environments such as mobile money transfer and internet-based e-commerce. Sadaruwan et al., (2018). andargued that trust is one of the key factors affecting the adoption of mobile money services, and trusted parties always to intend to use the service. Therefore, perceived trust is also likely to be a critical factor in the adoption of mobile money services because consumer trust in a company's integrity, benevolence and competence is pertinent in deciding to accept any transaction with it.

Therefore, this study proposes that trust affects the intention to use mobile money services. 
H4: There is a positive relationship between trust and the intention to use mobile money services

Knowledge includes the technology of the new service, complexity of the usage of the new service, and level of performance of the new service (Alkhunaizan and Love, 2012). Further, Walsham (2006), stated that knowledge is socially constructed and therefore subjective. According to the study by Iliasov (2014), lack of knowledge is a serious obstacle towards mobile money services adoption. Marcketti and Shelley (2009) highlighted that consumers' knowledge of products has a significantly positive effect on their perceived ease to use. Further, it can be stated that knowledge helps to recognize the innovation, the desire from new technologies, thereby applying the service faster and easier (Schreier and Prügl, 2008).

Lack of knowledge and education inversely affects mobile money services adoption (Finmark, 2016). Dzokoto and Appiah (2014) noted that a lack of knowledge is usually a common phenomenon among the poor. Similarly, Garcia-Murillo and Annabi, (2002) highlighted that knowledge helps the consumers to trade products or services easily, this is because users with a high level of understanding will use services better, more efficiently, and be able to avoid the risks.

Marcketti and Shelley (2009) claimed that consumers' knowledge of products has a significantly positive effect on their perceived ease to use. Customer's facts can help them identify what mobile payment can do for them and why the products/services are important to them. Furthermore, customers will consider what they will gain from the tools comparing with what they are having at the time regarding the services' quality, prices, insurance of privacy, etc. Customers will use mobile payments easily and efficiently if customers have a high level of knowledge about the tool they are conducting for mobile payments.
Thus, this research proposes that knowledge affects intention to use mobile money services.

H5: There is a positive relationship between knowledge and the intention to use mobile money services

\section{Moderating Effect of Demographic Factors}

Chawla and Joshi (2018) revealed that gender, age, income, experience, occupation, qualification, and marital status are the salient demographic variables, which moderate the impact of independent factors on user intention towards the use of mobile banking.

The study Abdinoor and Mbamba (2017) revealed that demographic characteristics of respondents (sex, age, and income level) are among the factors moderating the adoption of mobile financial services. Further, Abayomi, Olabode, Reyad, Teye, Haq and Mensah, (2019) argued through their research conducted in Nigeria, demographic factors such as age gender, income level, occupational level, except educational status do influence the adoption of mobile banking services in Benin City.

Marumbwa (2014) argued that through findings, the frequency of use of mobile money usage is largely influenced by the level of education and employment status whilst age, gender, and level of income have insignificant influence. In Lee et al.'s (2010) study, it was found that the direct impact of gender on intention is statistically insignificant. Jambulingam (2013) among Malaysian students' gender does not moderate the relationship between the determinants of mobile technology adoption and behavioral intention gender on intention is statistically insignificant. Demirci and Ersoy(2008) found that gender is a moderating variable for intention to use online services.

Im, Bayus and Mason (2003) research conducted in the US found that that the personal characteristics of age and income 
are stronger predictors of intention to new technologies. Further in the US, Porter and Donthu (2006) revealed that demographics factors are barriers to technology acceptance. In the same venue, Sun and Zhang (2006) stated that there is a moderating effect with demographic factors in user technology acceptance.

Onyia and Tagg (2011) revealed that based on their finding in the African country, the effects of demographic factors on bank customers' attitudes and intention toward internet banking adoption is very high.

Thus, this research proposes that demographic factors moderate the relationship between factors effecting intention to use mobile money services

H6 : There is a moderating effect of demographic factors on the relationship between the factors affecting on intention to use mobile money services

In this study Income level, Employment status (Job Title), Gender and Age were considered as moderating factors which can affect intention to use Mobile Money service. Therefore, following sub hypothesis were developed accordingly.

H6.1 Income significantly moderate relationship between the factors affecting on intention to use mobile money services

H6.2 Job title significantly moderate the relationship between the factors affecting on intention to use mobile money services

H6.3 Gender significantly moderate the relationship between the factors affecting on intention to use mobile money services

H6.4 Age significantly moderate the relationship between the factors affecting on intention to use mobile money services

Aforesaid models which are widely used in new technology acceptance and lterture reviews related to the mobile money services are very limited to find in sri lankan context. Further, factors effecting on intention to use mobile money service with the effect of demographic factors as moderator is rare to discover which really motivated to carry out this study and conceptual framework which was develpped based on above literature reviews are discussed in following pages.

\section{Conceptual Framework}

Based on the literature study key attributes which are identified, the factors affecting the user's intention to use the mobile money service are usefulness, awareness, knowledge, trust and risk. Further, it was identified that demographic factors moderate the relationship between usefulness, awareness, knowledge, trust and risk and the intention to use mobile moner services. Using these factors conceptual framework is defined to study the factors affecting intention to use mobile money services with moderating effect of demographic factors.

The conceptual model is defined for this study is shown in Figure 03.

\section{Research Methodology}

This study was carried out through a deductive approach, a quantitative perspective under objectivism. Therefore, both secondary and primary data were collected. In collecting primary data, the structured questioner was the main data collection method which used for the collection of data related to usefulness, awareness, knowledge, trust and risk in mobile money services. The questionnaire consists of three main sections, in the first section brief introduction is given to the respondent about the scope of the research and explain the objective of the questionnaire, in the second section questions are focused on collection demographic factors. The third section was intended to collect information related to the indicators developed based on the conceptual framework and pilot study was carried out using 30 responded to test the reliability of the questioners using Cronbach's Alpha analysis. 


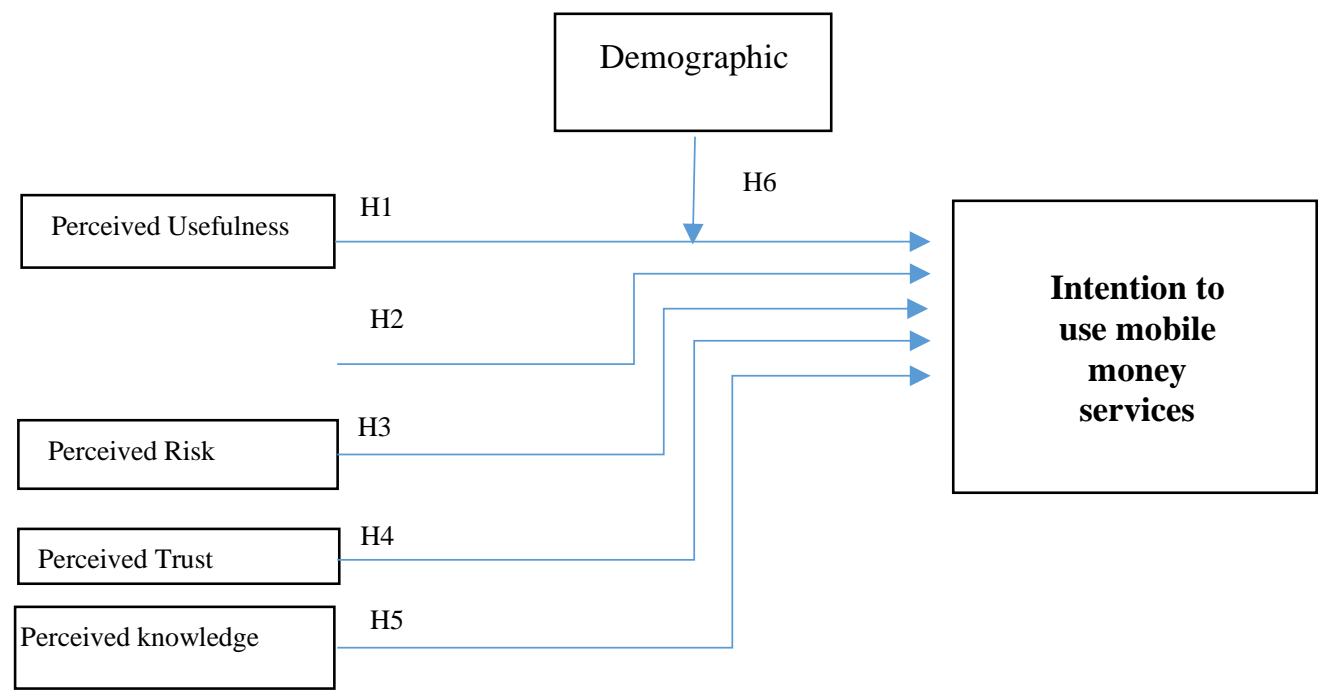

Figure 03: Conceptual framework

Source: Authors developed based on literature

Mobile users in the Western province of Sri Lanka were selected as the population for this study considering time and resource limitation in collecting the data from other geographical areas. According to Economynext (2019), 78\% of the population use mobile phones in Sri Lanka. In the same Perceived Awareness
venue it says that based on statistic department reviews, the Population of Western Province is about 6 million, whereas mobile users would be more than 4.5 million. As the population is more than 10000,400 samples were collected and analyzed based on Morgan's table guidelines.

The structured questioner was the data collection method used for the collection of data related to the hypothesis validation. The questionnaire consists of three main sections, in the first section brief introduction is given to the respondent about the scope of the research and explain the objective of the questionnaire, in the second section questions are focused on collection demographic factors. The third section was intended to collect information related to the indicators developed based on the conceptual framework.

Here random sampling technique was used and responses were selected randomly using excel generated random number sequence. 50 outlets were selected covering both Dialog and Mobitel outlets in western province for this exercise and number of persons were selected based on daily average visits of each outlet. Once 410 samples were collected, 10 incomplete questionnaires were removed and finally 400 samples were taken for the data analysis.

Data analysis was carried out using SPSS software and following tools were used to achieve the objective of the research.

Process Hayes model of SPSS was used to assess the impact of moderator effect and $\mathrm{P}<=0.05$ is considered as significant. 
Table 01: Tools used to measure the objectives

\begin{tabular}{|l|l|}
\hline \multicolumn{1}{|c|}{ Research Objective } & Statistical Tool \\
\hline $\begin{array}{l}\text { To identify the factors affecting on intention to use mobile money } \\
\text { services in the Telecommunication Industry. }\end{array}$ & Descriptive analysis \\
\hline $\begin{array}{l}\text { To assess the relationship of those factors on intention to use } \\
\text { mobile money services. }\end{array}$ & Correlation analysis \\
\hline $\begin{array}{l}\text { To examine whether demographic factors moderate the } \\
\text { relationship between factors affecting and intension to use mobile } \\
\text { money services }\end{array}$ & $\begin{array}{c}\text { Regression Analysis } \\
\text { - Process Hayes } \\
\text { model }\end{array}$ \\
\hline
\end{tabular}

\section{Data Analysis}

\section{Reliability Test}

It was noted that after reliability test, the questions had been asked for the measuring variables are valid and it was confirmed by the values of Cronbach's Alpha as shown table 02 .

Table 02: Reliability and validity Test

\begin{tabular}{|l|c|c|}
\hline \multicolumn{1}{|c|}{ Variable } & $\begin{array}{c}\text { Cronbach's } \\
\text { Alpha }\end{array}$ & $\begin{array}{c}\text { Number } \\
\text { of Items }\end{array}$ \\
\hline Usefulness & .960 & 4 \\
\hline Awareness & .880 & 6 \\
\hline Risk & .810 & 14 \\
\hline Trust & .721 & 7 \\
\hline Knowledge & .833 & 7 \\
\hline $\begin{array}{l}\text { User } \\
\text { Intention }\end{array}$ & .929 & 4 \\
\hline
\end{tabular}

\section{Normality Test}

Normality is defined by a symmetrical bellshaped curve. According to George and Mallery (2016), the arithmetic mean is a good descriptor if the Skewness value obtained is within \pm 2.0 cut-off point.

In this study, no extreme outliers were found in the findings after the normality tests were conducted and all fell within the acceptable range. Hence the total sample size of $\mathrm{N}=400$ remained. The normalized findings are presented in Table 03.

\section{Demographic analysis of the sample}

As per the total sample of 400, 76.5\% (306) of respondents were male in gender. The highest number $(41 \%)$ of the respondents is between the ages of 20 to 30 years. Age group, 31-40 years is the second-highest group with $36 \%$ and the age group 41-50 years are having $18 \%$ respondents. Finally, age above 50 years has $5 \%$ of respondents. The level of education consists of five categories. Primary, Secondary, Diploma, Degree, and Masters. According to the the analysis of the respondent's educational levels, $10 \%$ of respondents have completed only up to the secondary level of education. $30 \%$ of respondents are having diploma level as their highest level of education and the majority of the respondents are having a degree level of education which is $41 \% .18 \%$ are having a Master level of education.

When it comes to the categories of employees, $8 \%$ who are working in the government sector and $5 \%$ are selfemployed. The majority of $81 \%$ are working in the private sector. According to the income level, the majority of the responders in the industry have more than hundred thousand income per month $(61 \%)$ and number of participants whose income is more than two hundred thousand per month is $24 \%$. 
Sanjeewa, H.H.D., Yatigammana, M.R.K.N., KJM, 2021, 10 (02)

Table 03: Results of Normality analysis: Skewness and Kurtosis results

\begin{tabular}{|c|c|c|c|}
\hline \multicolumn{4}{|c|}{ Descriptive Analysis } \\
\hline \multirow{2}{*}{ Awareness } & & Statistic & Std. Error \\
\cline { 2 - 4 } & Skewness & -0.400 & 0.122 \\
\hline \multirow{2}{*}{ Risk } & Kurtosis & -0.227 & 0.243 \\
\cline { 2 - 4 } & Skewness & 0.140 & 0.122 \\
\cline { 2 - 4 } & Kurtosis & -0.129 & 0.244 \\
\hline \multirow{2}{*}{ Trust } & Skewness & -0.822 & 0.122 \\
\cline { 2 - 4 } & Kurtosis & 0.657 & 0.243 \\
\hline \multirow{2}{*}{ Knowledge } & Skewness & -1.086 & 0.122 \\
\cline { 2 - 4 } & Kurtosis & 0.995 & 0.243 \\
\hline \multirow{2}{*}{ Usefulness } & Skewness & -0.476 & 0.122 \\
\cline { 2 - 4 } & Kurtosis & -0.279 & 0.243 \\
\hline User Intention & Skewness & -0.393 & 0.122 \\
\cline { 2 - 4 } & Kurtosis & -0.132 & 0.24 \\
\hline
\end{tabular}

When its come to categories of employees, the majority is Executives (26\%) and the Senior Executive category is $16 \%$. $34 \%$ of the participants are Assistant Manager and above and $10 \%$ are those who engaged with self-employments, the education sector, etc.

Preliminary Analysis - Identification of factors

Several analyses were performed to validate the factors identified in literature. The central tendency and dispersion are the statistics that are frequently used to describe the data set. Descriptive statistics such as maximum, minimum, means and standard deviations were obtained for an interval, scale, dependent variable and all independent variables. According to table 04, all the variables (Independent variables and dependent variable) were above the average except Risk is below the average. Which confirmed that the selected independent variables from the literature is precise to Sri Lankan context as well.

Table 04: Central tendency and distribution of data

\begin{tabular}{|c|c|c|c|c|c|}
\hline \multirow{2}{*}{} & \multicolumn{5}{|c|}{ Descriptive Statistics } \\
\cline { 2 - 6 } & $\mathrm{N}$ & Minimum & Maximum & Mean Statistic & Std. Deviation Statistic \\
\hline Usefulness & 400 & 4 & 20 & 13.15 & 4.086 \\
\hline Trust & 400 & 7 & 35 & 23.41 & 5.331 \\
\hline Risk & 400 & 14 & 70 & 28.24 & 9.872 \\
\hline Awareness & 400 & 6 & 30 & 20.93 & 5.744 \\
\hline Knowledge & 400 & 7 & 35 & 25.24 & 5.944 \\
\hline User Intention & 400 & 4 & 20 & 14.20 & 3.400 \\
\hline
\end{tabular}


Inferential Analysis

Correlation Analysis

Pearson's correlation is employed to study the relationship between the independent variables (IVs) and the dependent variable (DV). Pearson's correlation coefficients (r) vary from -1 to +1 for the indication of positive or negative correlation. According to the study Pallant (2007), the size of the absolute correlation value formulates information on the strength of the relationship. The findings of the correlations between the independent variables and the dependent variables are summarized and presented in Table 05.

Table 05: Correlation Matrix

\begin{tabular}{|c|c|c|c|c|c|c|}
\hline \multicolumn{7}{|c|}{ Correlations } \\
\hline & & Usefulness & Knowledge & Awareness & Trust & Risk \\
\hline \multirow{3}{*}{$\begin{array}{c}\text { Intention to } \\
\text { Use }\end{array}$} & $\begin{array}{c}\text { Pearson } \\
\text { Correlation }\end{array}$ & $.690^{* *}$ & $.590^{* *}$ & $.582^{* *}$ & $.605^{* *}$ & $\begin{array}{c}- \\
.124^{* *}\end{array}$ \\
\hline & $\begin{array}{c}\text { Sig. (1- } \\
\text { tailed) }\end{array}$ & .000 & .000 & .000 & .000 & 0.007 \\
\hline & $\mathrm{N}$ & 400 & 400 & 400 & 400 & 400 \\
\hline
\end{tabular}

As results shown in Table 5.4 , there is a moderately positive significant relationship between Usefulness and Intension to use Mobile Money ( $\mathrm{r}=.690, \mathrm{p}=.000<0.05$ ). Hence, $\mathrm{H} 1$ is supported. As a result, higher Usefulness of users will increase the User Intention to use the Mobile Money service in Sri Lanka.

Similarly, there is a moderately positive significant relationship between Trust and Intension to use Mobile Money $(r=.605, p=$ $.000<0.05)$. Hence, $\mathrm{H} 2$ is supported. As a result, a higher Trust of users will increase the user Intention of use the Mobile Money service in Sri Lanka.

According to the findings, there is a significant weakly negative relationship between Risk and Intention to use Mobile Money $(r=-.124, p=.000<0.05)$. Therefore, $\mathrm{H} 3$ is supported. As a result, a higher Risk of users may decrease the User Intention to use the Mobile Money services in Sri Lanka.

Further, it was noted that there is a moderately positive significant relationship between Awareness and Intention to use Mobile Money $(\mathrm{r}=.582, \mathrm{p}=.000<0.05)$. Hence, H4 is supported. As a result, higher
Awareness of users will increase the user Intention to use the Mobile Money service in Sri Lanka.

Similarly, there is a moderately positive significant relationship between Knowledge and Intension to use Mobile Money ( $\mathrm{r}=.590$, $\mathrm{p}=.000<0.05$ ). Hence, H5 is supported. As a result, higher Knowledge of users will increase the user Intention of use the Mobile Money service in Sri Lanka.

Moderation Affect of Demographic Factors On the Relationship Between Independent and Dependent Variables - Regression Analysis

Process Hayes model of SPSS was used to assess the impact of moderator effect. In this analysis, demographic factors such as Gender, Income, Job Title, and Age were used to create dummy variables and assessed the moderation effect on the relationship between independent and dependent variables. 
Table 06: Moderation impact of Demographic factors

\begin{tabular}{|c|c|c|c|c|c|c|c|}
\hline \multicolumn{8}{|c|}{ Moderator impact } \\
\hline \multirow{2}{*}{ Moderator } & \multirow{2}{*}{ Level } & \multirow{2}{*}{$\begin{array}{c}\text { Key } \\
\text { Indicator }\end{array}$} & \multicolumn{5}{|c|}{ Independent variable } \\
\hline & & & Usefulness & Awareness & Trust & Knowledge & Risk \\
\hline \multirow[b]{2}{*}{ Gender } & \multirow{2}{*}{ Male } & Sig & 0.9473 & 0.7447 & 0.0804 & 0.1387 & 0.179 \\
\hline & & Beta & 0.0049 & 0.0216 & 0.1228 & 0.0837 & -0.0558 \\
\hline \multirow{5}{*}{ Income } & \multirow{2}{*}{$50000-100000$} & Sig & 0.1829 & 0.6539 & 0.4391 & 0.9238 & 0.0048* \\
\hline & & Beta & -0.1062 & -0.0335 & -0.0564 & -0.0063 & 0.1290 \\
\hline & \multirow{2}{*}{$100000-150000$} & Sig & 0.1174 & 0.0478* & 0.0519 & 0.5437 & 0.7761 \\
\hline & & Beta & -0.1161 & -0.1059 & -0.1187 & -0.0349 & 0.0129 \\
\hline & Above 200000 & Beta & -0.0114 & 0.0311 & 0.0268 & 0.0561 & -0.0807 \\
\hline \multirow{4}{*}{ Job Title } & \multirow[t]{2}{*}{ S. Manger or Above } & Sig & 0.1597 & 0.9032 & 0.1161 & 0.4335 & 0.2090 \\
\hline & & Beta & -0.1216 & -0.0097 & -0.121 & 0.0604 & 0.0607 \\
\hline & \multirow[t]{2}{*}{ Manager } & Sig & 0.5230 & 0.9214 & 0.7351 & 0.4306 & $0.0367 *$ \\
\hline & & Beta & 0.0582 & 0.0068 & -0.0252 & -0.0537 & -0.1060 \\
\hline
\end{tabular}


Sanjeewa, H.H.D., Yatigammana, M.R.K.N., KJM, 2021, 10 (02)

\begin{tabular}{|c|c|c|c|c|c|c|c|}
\hline & A. Manager & Sig & 0.6702 & 0.7226 & 0.3411 & 0.8381 & 0.5761 \\
\hline & & Beta & 0.0475 & 0.0276 & 0.0792 & -0.0151 & 0.0422 \\
\hline & Senior Executive & Sig & 0.2162 & 0.8447 & 0.8662 & 0.8271 & 0.7544 \\
\hline & & Beta & 0.1043 & 0.0130 & 0.0121 & -0.0142 & 0.0145 \\
\hline & Executive & Sig & $0.0306^{*}$ & 0.5413 & 0.3203 & 0.1525 & 0.9404 \\
\hline & & Beta & -0.1560 & -0.0385 & -0.0644 & -0.0817 & -0.0031 \\
\hline & Officer & Sig & $0.0353 *$ & 0.1041 & 0.0818 & 0.0669 & 0.5770 \\
\hline & & Beta & 0.1708 & 0.1058 & 0.1086 & 0.1063 & -0.0253 \\
\hline \multirow{8}{*}{ Age } & \multirow{2}{*}{$20-30$} & Sig & 0.5493 & 0.5743 & 0.2619 & 0.1062 & 0.3251 \\
\hline & & Beta & -0.0372 & -0.0284 & 0.0612 & -0.0768 & 0.0352 \\
\hline & \multirow{2}{*}{$30-40$} & Sig & 0.2162 & 0.2211 & 0.9786 & 0.2146 & 0.8138 \\
\hline & & Beta & 0.0777 & 0.0609 & -0.0014 & 0.0611 & -0.0085 \\
\hline & \multirow{2}{*}{$40-50$} & Sig & 0.2917 & 0.2992 & 0.2982 & 0.4757 & 0.5461 \\
\hline & & Beta & -0.0816 & -0.0604 & -0.0635 & 0.0403 & -0.0238 \\
\hline & \multirow{2}{*}{$50-60$} & Sig & 0.7103 & 0.9276 & 0.7655 & 0.7156 & 0.7795 \\
\hline & & Beta & 0.0586 & 0.0181 & -0.0385 & -0.0478 & -0.0444 \\
\hline \multicolumn{2}{|c|}{${ }^{*}$ Significant at 0.05 confidence level } & & & & & & \\
\hline
\end{tabular}


Table 06 shows the moderator impact of demographic factors on the relationship between factors affecting the intention to use Mobile Money. There is a significant moderation impact of the 25000 - 50000 income level category on the relationship between knowledge and the intention to use mobile money $(\mathrm{B}=-0.13, \mathrm{p}=0.0234<0.05)$. There is a significant moderation impact of the 50000-100000 income level category on the relationship between risk and the intention to use mobile money $(\mathrm{B}=-0.129, \mathrm{p}=$ $0.0048<0.05)$. There is a significant moderation impact of the 100000-150000 income level category on the relationship between awareness and the intention to use mobile money $(\mathrm{B}=-0.1059, \mathrm{p}=$ $0.0478<0.05)$. There is a significant moderation impact of 150000-200000 income level category on the relationship of usefulness $(\mathrm{B}=0.2831, \mathrm{p}=0.0012<0.05)$, awareness $(\mathrm{B}=0.1812, \mathrm{p}=0.0076<0.05)$ and trust $(\mathrm{B}=0.1600, \mathrm{p}=0.0186<0.05)$ with the intention to use mobile money. There is a significant moderation impact of the above 200000 income level category on the relationship between risk and the intention to use mobile money $(\mathrm{B}=-0.0807, \mathrm{p}=$ $0.0353<0.05)$.

Further, as shown in Table 4.6, there is a significant moderation impact of the officer category on the relationship between usefulness and the intention to use mobile money $(B=0.1708, p=0.0353<0.05)$. The moderation impact of the Executive category on the relationship between usefulness and the intention to use mobile money in Significant $(B=-0.1560, p=0.0306<0.05)$. Also, there is a significant moderation impact of the Manager category on the relationship between risk and the intention to use mobile money $(\mathrm{B}=-0.1060, \mathrm{p}=0.0367<0.05)$.

\section{Results}

\section{Hypothesis Testing}

Table 07: Summary of the Hypothesis Testing

\begin{tabular}{|l|c|c|}
\hline \multicolumn{1}{|c|}{ Hypothesis } & P_Value $_{-}$ & Decision \\
\hline $\begin{array}{l}\text { H1: There is a positive relationship between Perceived } \\
\text { Usefulness and the intention to use mobile money services }\end{array}$ & 0.000 & Supported \\
\hline $\begin{array}{l}\text { H2: There is a positive relationship between Awareness and } \\
\text { the intention to use mobile money services }\end{array}$ & 0.000 & Supported \\
\hline $\begin{array}{l}\text { H3: There is a Negative relationship between Risk and } \\
\text { Intention to use Mobile Money services }\end{array}$ & 0.007 & Supported \\
\hline $\begin{array}{l}\text { H4: There is a positive relationship between Trust and the } \\
\text { intention to use mobile money services }\end{array}$ & 0.000 & Supported \\
\hline $\begin{array}{l}\text { H5: There is a positive relationship between Knowledge and } \\
\text { the intention to use mobile money services }\end{array}$ & 0.000 & Supported \\
\hline
\end{tabular}

The Pearson correlation has indicated that there is a significant positive relationship between the Perceived Usefulness of the users and their Intention to use Mobile Money service in Sri Lanka. This finding is consistent with the findings of Naiwumbwe (2012) and Shanmugam, Savarimuthu and
Wen (2014) in Malaysia, found that there is a significant positive impact on perceived usefulness on attitude towards using mobile banking support services. This is justifiable because usefulness always invites the user to use the product or service. 
Further, it has indicated that there is a positive relationship between Awareness of the users and their Intention to use Mobile Money service in Sri Lanka. These findings are consistent with the findings of Laforet and $\mathrm{Li}$ (2005), Tobbin (2013), and Jillbert and Ahmad (2003) in Australia. This is justifiable because awareness provides an understanding of the existence of the product that they wish to buy in the future.

As per the findings of this study it was indicated that there is a negative significant relationship between Risk and Intention to use Mobile Money services. This finding is consistent with the findings of Havlena and DeSarbo, (1991) in the United States and Sadaruwan et al., (2018) in Sri Lanka. This is justifiable as risk is always limited to the user's intention to use any product or service.
On the other hand, similar to the findings of Chiu, Bool and Chiu (2017) in the Philippines, the result of this research also evidenced that there is a positive relationship between Trust and Intention to use of Mobile Money services. This is justifiable because Trust always invites the user to use the product or service.

Finally, this study provides evidence that there is a positive relationship between users' knowledge and intention to use Mobile Money services. Similarly, Marcketti and Shelley (2009) have identified a positive relationship between knowledge and user intention. It is consistent with the finding of Jillbert and Ahmad (2003) also in Australia.

Regression analysis - Process Hayes model of SPSS was used to assess the impact of moderator effect on demographic factors.

Table 08: Summary of Moderation Impact on Demographic Factors

\begin{tabular}{|l|c|}
\hline \multicolumn{1}{|c|}{ Hypothesis } & Decision \\
\hline $\begin{array}{l}\text { H 6.1 Income significantly moderate relationship between the factors } \\
\text { affecting on intention to use mobile money services }\end{array}$ & Supported \\
\hline $\begin{array}{l}\text { H 6.2 Job title significantly moderate the relationship between the factors } \\
\text { affecting on intention to use mobile money services }\end{array}$ & Supported \\
\hline $\begin{array}{l}\text { H 6.3 Gender significantly moderate the relationship between the factors } \\
\text { affecting on intention to use mobile money services }\end{array}$ & $\begin{array}{c}\text { Not } \\
\text { Supported }\end{array}$ \\
\hline $\begin{array}{l}\text { H 6.4 Age significantly moderate the relationship between the factors } \\
\text { affecting on intention to use mobile money services }\end{array}$ & $\begin{array}{c}\text { Not } \\
\text { Supported }\end{array}$ \\
\hline
\end{tabular}

Zhang and Prybutok (2003) research conducted in the United States and Chawla, D., and Joshi, H. (2018) research conducted in India stated that Gender has a moderating effect between the ease of use and intention to use mobile services. As per the finding of this study, it was revealed that Age doesn't moderate the factors affecting Intention to use Mobile Money in the Sri Lankan context and it is in line with the finding of Jambulingam (2013) in Malaysia.
The findings related to Income is consistent with the findings of Im, S., Bayus, B. L., and Mason, C. H. (2003) research conducted in United State found that the personal characteristics of income is stronger predictors of intention to new technologies. The findings of this study revealed that income significantly moderate the relationship between the factors affecting on intention to use Mobile Money services.

Marumbwa, J. (2014) argued that through his findings in Zimbabwe, the frequency of use 
of Mobile Money usage is largely moderated by the level of education and employment status whilst age, gender, and level of income have insignificant influence. As per the findings of this study, it is noticed that age and gender do not moderate the usage of mobile money, but employment status is significantly moderate the mobile money usage in Sri Lankan context as well. Education did not consider in this study as a moderator but considered income level and employment status as those two are directly related to education level.

\section{Conclusion}

The study was carried out to analyze the factors affecting intention to use the Mobile Money Service in Sri Lanka with the moderating affect of demographic factors with reference to the Western Province of Sri Lanka. There were five motives identified based on the literature and a conceptual framework was developed based on that. Usefulness, awareness, knowledge, trust and risk are recognized as the main contributors to the user intention of using Mobile Money service. Gender, age, income level and job title were considered as moderating factors of the relationship between independent and dependent variables. Based on the literature survey it was expected that all the factors are positively influencing the user's intention except for the risk which is having a negative influence. It was identified that in the sample, the current level of usefulness, awareness, knowledge are below the level of 4 on the five-point Likert scale while Trust and Risk are below the neutral level of 3 on the fivepoint Likert scale.

Five factors that were identified through a literature survey were tested using hypotheses to examine the relationships that those factors have on the User Intention. According to the findings, hypotheses related to Usefulness, Trust, Awareness, and Knowledge are supported as " $p$ " values are less than 0.05 and positively related with the user Intention. As expected findings proved that there is a significant negative relationship between Risk and user intention to use Mobile Money. Therefore, hypotheses related to Risk are also supported $(\mathrm{p}=0.007)$.

Further, the moderating affect of demographic factors on the above five factors was discussed and it was noted that gender and age do not moderate the relationship between the above five factors and User Intention but Income level and Job Title (Employment Status) moderator the relationship of above factors and User Intention.

\section{Recommendations}

Analysis results showed that there is a positive relationship between users' usefulness, awareness, knowledge, trust, and users' intention while risk is having a negative relationship. Further, it revealed that demographic factors moderate the effect of the above five factors on intention to use mobile money. It was noted that gender and age do not moderate but income level and job title (employment status) moderator the relationship between the above factors and user intention. Therefore, enlightening these factors would interest more users to use the services and thereby collect more users to the service.

Usefulness is identified as one of the factors which are affecting intention to use Mobile Money service. It is proven that at the situation like Covid-19, as it will limit the usage of physical money transactions between the people which reduces the risk of spreading diseases. The benefit of the service should be clearly communicated targeting different income levels and employment as such demographic factors directly impact the intention to use and it will help to accommodate to more users for the service. Also, operators should design service packages with usage levels and provide denifites considering the demographic factors as well. That will help operators to win the consumer's mind easily.

Further, it was identified that trust plays a vital role in adopting new products. Brand image, brand loyalty are the main 
components and continues guaranteed service enhance the brand trust and hence it is important to improve the trust in new products. Launching loyalty programs and provide benefits to users who are staying on a long-term basis will help to bring more users to new services as well as improve brand loyalty and brand image. Campaign targeting different income level and employment level would also help to reach more consumers as those demographic factors show the moderating impact of user Intention. Operaors can prioritize the customer base and provide offers, discounts and priority service and red-carpet zones in service centers are a few of the activities that can be used to build the loyalty of customers. Those activities improve the trust and thereby improve the intention to use the service offered by the operators.

The study revealed that there is a significant negative relationship between the perceived Risk and User Intention of Mobile Money services. This means that the user's intention to use the service will be reduced while increasing the risk thus operators should take necessary steps to keep this factor as low as possible. Steps taken by the mobile operators to increase the safety factors, service level, including personal security codes to log to the system may lead to change consumer's minds and reduce the effect. Introducing SMS alert when logging t the system makes customers more secure and confident. As this is a very sensitive area continuous communication about the security level of the service would help to build trust in consumer's mind. Further, continuous development of the infrastructure to protection the personal information of the users as well as protection transactions and improve the accessibility and service availability are the key areas that need to be addressed and continuously develop. All actions that are taking to minimize the risk should be continuously communicated to the consumer with a proper marketing chnnels which will help to keep risk factors in consumer minds at a minimum level. While doing such campaigns income level and employment status should also be considered as those factors moderate the impact.

Awareness is also identified as one of the factors which are affecting the Intention to use Mobile Money service. It is important to make sure that consumers are aware of the presence of the product and hence service providers must do extra consideration on making the individuals updated on the new products or the services introduced by them. Extra efforts on marketing will help to take products to the customers and make it resonance on their minds. All kind of medias canbe used in different levels. This includes above the level and below the level marketing channels, such as TV, Radio, Facebook, Instagram, WhatsApp, Twitter, etc. Specially the platforms like social media can use to build product awareness with a lesser amount of cost compared to the marketing channels of above the level. On the other hand these social media platforms are very popular among the young generation, who will become the next set of customers of this kind of new products. Offering free trials and attractive discounts are also help to imcrease the awareness among the customers. Since the mobile operators already have a huge customer base, they can offer free registration and free service usage for a specific period for their existing customers which will help to cater more customers to the new service. All above marketing campaigns would be essential to target different income levels and employment levels as those demographic factors moderate the relationship of intention to use Mobile Money services.

The next factor identified in the study is the knowledge of the new product and its usage. It was proven that increasing product knowledge has a positive relationship with the user intention on Mobile Money service. Therefore, it is very much essential to have a plan to increase the knowledge of this service and should consider the consumers at different income levels and employment levels as those demographic factors moderator the intention to use Mobile Money. There are many components that 
have a direct impact on product knowledge. Technology, Performance, Usage, and Complexity are key factors among them. Arranging training, circulate user manuals are the simple activities that a company can do to improve the user's knowledge of the service or product. Further marketing campaigns to educate peoples about the new product will help to touch the costermoers mind more effectively.

\section{Limitations and Future Research}

Even though this study discussed a lot on factors affecting intention to use mobile money services, practically the following limitations were identified. This study is limited to the Western province of Sri Lanka and that is due to time and resources limitation in collecting the data from other geographical areas. Therefore, it is recommended to undertake similar studies covering all districts which will provide a better understanding of the user's Intention of the Mobile Money service in Sri Lanka. On the other hand, only five factors were considered during this study as factors affecting the intention to use mobile money, but future researchers can consider other variables that can affect on the intention to use Mobile Money services. Further, Gender, Age, Employment status, and Income level were considered as moderating factors of the relationship between independent and dependent variables and future researchers can evaluate the impact of other demographic factors as well. 


\section{References}

Abayomi, O. J., Olabode, A. C., Reyad, M. A. H., Teye, E. T., Haq, M. N., and Mensah, E. T. (2019). Effects of Demographic Factors on Customers' Mobile Banking Services Adoption in Nigeria. International Journal of Business and Social Science, 10(1), 63-77. https://doi:10.30845/ijbss.v10n1p1

Abdinoor, A., and Mbamba, U. O. (2017). Factors influencing consumers' adoption of mobile financial services in Tanzania. Cogent Business and Management, 4(1), 1392273. https://doi.org/10.1080/23311975.2017.1392273

Alkhunaizan, A., and Love, S. (2012). What drives mobile commerce? An empirical evaluation of the revised UTAUT model. International Journal of Management and Marketing Academy, 2(1), 82-99. https://doi.org/0.1016/j.im.2004.07.001

Amoroso, D. L., and Watanabe, M. R. (2012). Building a research model for mobile wallet consumer adoption: the case of mobile Suica in Japan. Journal of theoretical and applied electronic commerce research,7(1), 94-110. https://doi.org/10.4067/S071818762012000100008

Anckar, B., and Walden, P. (2003). Factors affecting consumer adoption decisions and intents in mobile commerce: Empirical insights. BLED 2003 Proceedings, 28.

Ba, S., and Pavlou, P. A. (2002). Evidence of the effect of trust building technology in electronic markets: Price premiums and buyer behavior. MIS quarterly, 243-268.

Bauer, H. H., Barnes, S. J., Reichardt, T., and Neumann, M. M. (2005). Driving consumer acceptance of mobile marketing a theoretical framework and empirical study. Journal of Electronic Commerce Research, 6(3), 181 - 192.

Bhattacherjee, A. (2002). Individual trust in online firms: Scale development and initial test. Journal of management information systems, 19(1), 211-241. https://doi.org/10.1080/07421222.2002.11045715

Castri, S. (2013). Enabling Mobile Money Policies in Sri Lanka the rise of eZ Cash. Available at SSRN 2302736.

Central Bank of Sri Lanka. (2011). Annual Report of Central Bank of Sri Lanka 2011. Retrieved from: https://www.cbsl.gov.lk/en/directions-circulars-and-guidelines.

Central Bank of Sri Lanka. (2018). Annual Report of Central Bank of Sri Lanka 2018. Retrieved from:

http://www.cbsl.gov.lk/pics_n_docs/10_pub/_docs/efr/annual_report/AR2018

Chawla, D., and Joshi, H. (2018). The moderating effect of demographic variables on mobile banking adoption: an empirical investigation. Global Business Review, 19(3_suppl), S90S113. https://doi.org/10.1177/0972150918757883 
Sanjeewa, H.H.D., Yatigammana, M.R.K.N., KJM, 2021, 10 (02)

Chen, C. (2013). Perceived risk, usage frequency of mobile banking services. Managing Service Quality: An International Journal, 23(5), 410-436. https://doi.org/10.1108/MSQ-102012-0137

Chen, H. (2008). Individual Mobile Communications Services and Tariffs.

Chen, L., Gillenson, L., and Sherrell, L. (2002). Enticing online consumers: an extended technology acceptance perspective, 39 (8), 709-719. https://doi: 10.1016. S0378-7206 (01), 00127-6.

Chiu, J. L., Bool, N. C., and Chiu, C. L. (2017). Challenges and factors influencing initial trust and behavioral intention to use mobile banking services in the Philippines. Asia Pacific Journal of Innovation and Entrepreneurship. https://doi.org/2071-1395 DOI 10.1108/APJIE08-2017-029

Demirci, A. E., and Ersoy, N. F. (2008). Technology readiness for innovative high-tech products: how consumers perceive and adopt new technologies. The Business Review, 11(1), 302-308.

Dialog Axiata PLC. (2017). Annual Report of Dialog Axiata PLC 2017. Retrieved from https://www.dialog.lk/dialogdocroot/content/pdf/annual_reports/2017-annual-report.pdf

Dialog Axiata PLC. (2018). Annual Report of Dialog Axiata PLC 2018. Retrieved from https://www.dialog.lk/dialogdocroot/content/pdf/annual_reports/2018-annual-report.pdf

Dzokoto, V. A., and Appiah, E. (2014). Making sense of mobile money in urban Ghana: Personal, business, social and financial inclusion prospects. Institute for Money, Technology and Financial Inclusion (IMTFI). University of California, Irvine.

Economynext (2019), About clinical psychology. Retrieved from https://economynext.com/sri-lanka-mobile-money-use-still-low-survey-finds-14147/

Finmark T. (2016). The role of mobile money in financial inclusion in the SADC region. Retrieved from https://www.finmark.org.za/wp-content/uploads/2016/12/mobile-moneyand-financial-inclusion-insadc.pdf

Fishbein, M. (1979). A theory of reasoned action: some applications and implications.

Garcia-Murillo, M., and Annabi, H. (2002). Customer knowledge management. Journal of the Operational Research Society, 53, 875-884.

George, D., and Mallery, P. (2016). Frequencies. In IBM SPSS Statistics 23 Step by Step (pp. 115-125). Routledge.

Gong, M., Xu, Y., and Yu, Y. (2004). An enhanced technology acceptance model for webbased learning. Journal of Information Systems Education, 15(4). 
GSMA Mobile Money. (2017). State of the Industry Report on Mobile Money, Retrieved from https://www.gsma.com/mobilefordevelopment/wpcontent/uploads/2018/05/GSMA 2017 State of the Industry Report on Mobile Money Full Report.pdf

Hohenberg, H., and Rufera, S. (2004). The mobile phone as a wallet of the future: opportunities and potentials of the mobile payment. the market: Journal of Economics and paragraph Marketing, 43(168), 33-40.

Holmes, J.G. (1991), Trust and the appraisal process in close relationships", In Jones, W.H. and Perlman, D. (Eds), Advances in Personal Relationships, 2, Jessica Kingsley, London, 57-104.

Ilyasova, A. (2014). Barriers to mobile money adoption in Nigeria. Retrieved from http://finclusion.org/blog/barriers-to-mobile-money-adoption-in-nigeria.html

Im,S., Bayus, B. L., and Mason, C. H. (2003). An empirical study of innate consumer innovativeness, personal characteristics, and new-product adoption behavior. Journal of the academy of marketing science, 31(1), 61-73. https://doi.org/10.1177/0092070302238602

International Telecommunications Union (ITU). 2019. World Telecommunication/ICT Indicators Database. Retrieved from http://www.itu.int/ITUD/ict/statistics/material/graphs/Global mobile cellular_00-09.jpg

Jack, W., and Suri, T. (2014). Risk sharing and transactions costs: Evidence from Kenya's mobile money revolution. The American Economic Review, 104(1), 183-223. https://doi: 10.1257/aer.104.1.183

Jambulingam, M. (2013). Behavioural intention to adopt mobile technology among tertiary students. World applied sciences journal,22(9), 1262-1271. https://doi: 10.5829/idosi.wasj.2013.22.09.2748

Jenkins, B. (2008). Developing mobile money ecosystems. Washington, DC: International Finance Corporation and Harvard Kennedy School.

Jensen A. K., (2017). Mobile Money Adoption in East Africa: A cross-country study of bestandleast-performing countries.

Jillbert, J., and Ahmad, K. (2003). Adoption, diffusion, use and impact of m-commerce within campus community: a survey of international students. Proceedings of the 15th Annual SPUSC 2003: The Drive to be Different, 00-00.

Kim, D. J., Ferrin, D. L., and Rao, H. R. (2008). A trust-based consumer decision-making model in electronic commerce: The role of trust, perceived risk, and their antecedents. Decision support systems, 44(2), 544-564.

https://doi.org/10.1016/j.dss.2007.07.001

Laforet, S., and Li, X. (2005). Consumers' attitudes towards online and mobile banking in China. International journal of bank marketing. https://doi.org/10.1108/02652320510629250 
Lal, R., and Sachdev, I. (2015). Mobile money services-Design and development for financial inclusion. Harvard Business School. Working Paper 15-083.

Lewicki, R.J., Tomlinson, E.C., and Gillespie, N. (2006), "Models of interpersonal trust development: theoretical approaches, empirical evidence, and future directions", Journal of Management, 32(6), 991-1022. https://doi.org/10.1177/0149206306294405

Li, F., and Whalley, J. (2002). Deconstruction of the telecommunications industry: from value chains to value networks. Telecommunications policy, 26(9-10), 451472.https://doi.org/10.1016/S0308-5961(02)00056-3

Marcketti, S., and Shelley, M. (2009). Consumer concern, knowledge and attitude towards counterfeit apparel products. International Journal of Consumer Studies, 33(3), 327-337. https://doi.org/10.1111/j.1470-6431.2009.00748.x

Marumbwa, J. (2014). Exploring the moderating effects of socio-demographic variables on consumer acceptance and use of mobile money transfer services (MMTs) in Southern Zimbabwe. American Journal of Industrial and Business Management, 2014. https://doi.org/10.4236/ajibm.2014.42011

Mayer, R. C., Davis, J. H., and Schoorman, F. D. (1995). An integrative model of organizational trust. Academy of management review, 20(3), 709-734. https://doi.org/10.2307/258792

Molla, G. (2015). Assessment of agent banking challenges of united bank share company (doctoral dissertation, St. Mary's University).

Naiwumbwe, M. (2012). Perceived ease of use, perceived usefulness, behavioral intention to use, and acceptance of mobile money transfer services (Doctoral dissertation, Makerere University).

Onyia, O. P., and Tagg, S. K. (2011). Effects of demographic factors on bank customers' attitudes and intention toward Internet banking adoption in a major developing African country. Journal of Financial Services Marketing, 16(3-4), 294-315. https://doi.org/10.1057/fsm.2011.28

Pavlou, P. (2001). Integrating Trust in Electronic Commerce with the Technology Acceptance Model: Model Development and Validation. AMCIS 2001 Proceedings,159. Retrieved from http://aisel.aisnet.org/amcis2001/159

Porter, C. E., and Donthu, N. (2006). Using the technology acceptance model to explain how attitudes determine Internet usage: The role of perceived access barriers and demographics. Journal of business research, 59(9), 999-1007. https://doi.org/10.1016/j.jbusres.2006.06.003

Pura, M. (2005). Linking perceived value and loyalty in location-based mobile services. Managing service quality, 15(6), 509-538.

https://doi.org/10.1108/09604520510634005 
Rogers, E.M., 2003. Diffusion of innovations (Fifth Edition). Free Press, New York,

Sadaruwan, A., Samarasinghe, D., and Kuruppu, G. (2018). Factors affecting the adoption of mobile money services in the Colombo district Sri Lanka. Internatioanl Research Conference on Management and Finance University of Colombo,Sri Lanka.

Schreier, M., and Prügl, R. W. (2008). Extending lead user theory: Antecedents and consequences of consumers' lead userness. Journal of Product Innovation Management, 25(4), 31-346. https://doi.org/10.1111/j.1540-5885.2008.00305.x

Silva, K. A., and Yapa, S. T. W. S. (2013). Customer retention: with special reference to telecommunication industry in Sri Lanka.

Srinivasan, R., Lilien, G.L., and Rangaswamy, A. (2002). "Technological opportunism and radical technology adoption: an application to e-business", Journal of Marketing, 66(3), 4760. https://doi.org/10.1509/jmkg.66.3.47.18508

Telecommunication Regulatory Commission of Sri Lanka (TRCSL) (2014). Annual Report of Telecommunication Regulatory Commission of Sri Lanka 2014.

Thakur, R., and Srivastava, M. (2014). Adoption readiness, personal innovativeness, perceived risk and usage intention across customer groups for mobile payment services in India. Internet Research. https://doi.org/10.1108/IntR-12-2012-0244

Tobbin, P. (2013). Towards a model of adoption in mobile banking by the unbanked: A qualitative study. Info, 14(5), 74-88.

Walsham, G. (2006). Doing interpretive research. European Journal of Information Systems, 15(3),320330. Retrieved from https://doi.org/10.1057/palgrave.ejis.3000589

Wears, R. L., and Berg, M. (2005). Computer technology and clinical work: still waiting for Godot. Jama, 293(10), 1261-1263.

Yousafzai, S. Y., Pallister, J. G., and Foxall, G. R. (2003). A proposed model of e-trust for electronic banking. Technovation, 23(11), 847-860.

Yu, S., and Ibtasam, S. (2018). A qualitative exploration of Mobile money in Ghana. In Proceedings of the 1st ACM SIGCAS Conference on Computing and Sustainable Societies (pp. 1-10).

Zhang, X., and Prybutok, V. R. (2003). TAM: The moderating effect of gender on online shopping. Journal of International Information Management, 12(2), 8. 